\title{
Analysis of records by nursing technicians and nurses in medical records
}

\author{
Análise dos registros de técnicos de enfermagem e enfermeiros em prontuários \\ Análisis de los registros médicos de técnicos de enfermería y de enfermeros
}

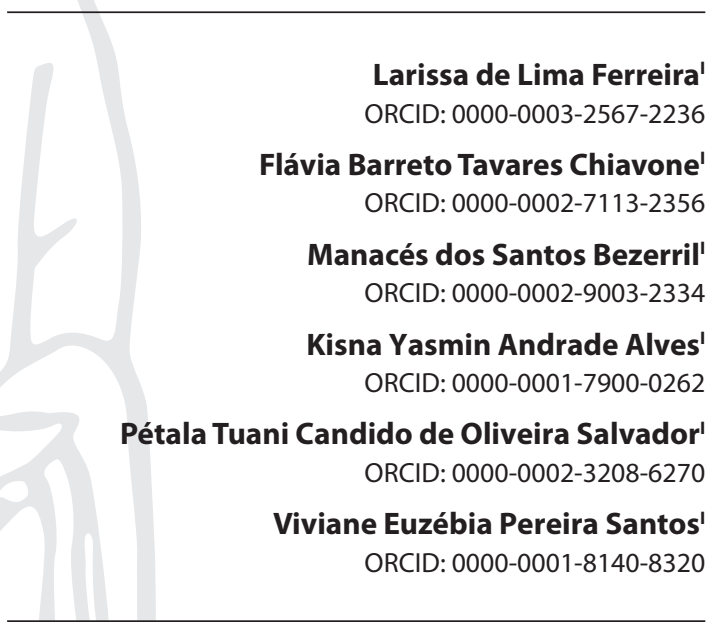

'Universidade Federal do Rio Grande do Norte. Natal, Rio Grande do Norte, Brazil.

How to cite this article: Ferreira LL, Chiavone FBT, Bezerril MS, Alves KYA, Salvador PTCO, Santos VEP. Analysis of records by nursing technicians and nurses in medical records. Rev Bras Enferm. 2020;73(2):e20180542. doi: http://dx.doi.org/10.1590/0034-7167-2018-0542

Corresponding Author:

Flávia Barreto Tavares Chiavone flavia_tavares@hotmail.com

EDITOR IN CHIEF: Dulce Aparecida Barbosa ASSOCIATE EDITOR: Alexandre Balsanelli

Submission: 07-01-2018 Approval: 09-09-2019

\begin{abstract}
Objectives: to analyze the main non-conformities of the nursing records of a public hospital in Natal, Brazil. Methods: this is a descriptive, cross-sectional study, with a quantitative approach. This study was conducted in nursing departments of medical and surgical wards. The sample was composed of 120 medical records of inpatients between October and December 2016. The obtained data were tabulated and analyzed by simple statistics in absolute and relative frequency using the 2013 Microsoft Excel software. The Pareto Diagram was used to evaluate the non-conformities of the records. Results: the main problems in the nursing records were the absence of the professional category and the nursing council number, responsible for $41.8 \%$ of the non-conformities in the records of nursing technicians; for nurses' records, the main non-conformities were the absence of time and the illegible handwriting, with $61.2 \%$. Conclusions: the study showed that nursing professionals perform their records incompletely and often do not document the care provided.
\end{abstract}

Descriptors: Nursing. Communication. Nursing records. Patient safety. Health Services Research.

\section{RESUMO}

Objetivos: analisar as principais não conformidades dos registros de enfermagem de um hospital público do Nordeste na cidade de Natal. Métodos: estudo descritivo, transversal abordagem quantitativa. Realizado em enfermarias médicas e cirúrgicas. Amostra composta de 120 prontuários de pacientes internados entre outubro e dezembro de 2016. Os dados obtidos foram tabulados e analisados por estatística simples em frequência absoluta e relativa com o software Microsoft Excel 2013. Para avaliar as não conformidades dos registros, usou-se o Diagrama de Pareto. Resultados: como principais problemas nos registros de enfermagem, destacou-se a ausência da categoria profissional e número do conselho, responsáveis por $41,8 \%$ das não conformidades nos registros de técnicos de enfermagem, enquanto nas anotações dos enfermeiros foram a ausência de hora e as letras ilegíveis, com $61,2 \%$. Conclusões: o estudo evidenciou que os profissionais de enfermagem realizam seus registros de forma incompleta e que muitas vezes não documentam o cuidado prestado. Descritores: Enfermagem; Comunicação; Registros de Enfermagem; Segurança do Paciente; Pesquisa Sobre Serviços de Saúde.

\section{RESUMEN}

Objetivos: evaluar las no conformidades principales de los registros de enfermería de un hospital público del Nordeste en la ciudad de Natal (Brasil). Métodos: estudio descriptivo, transversal, de enfoque cuantitativo. Se llevó a cabo en enfermerías médicas y quirúrgicas. La muestra constó de 120 registros médicos de pacientes hospitalizados entre octubre y diciembre de 2016. Los datos obtenidos fueron tabulados y analizados por estadística simple en frecuencias absoluta y relativa con el software Microsoft Excel 2013. Se utilizó el Diagrama de Pareto en la evaluación de las no conformidades de los registros. Resultados: entre los principales problemas en los registros de enfermería, se destacó la ausencia de la categoría profesional y del número de la comisión, responsables de un $41,8 \%$ de las no conformidades en los registros de técnicos de enfermería, mientras que en las anotaciones de los enfermeros se sobresalió la ausencia de hora y caligrafía ilegible, con un $61,2 \%$. Conclusiones: el estudio demostró que los profesionales de enfermería hacen sus registros de forma incompleta y que muchas veces no documentan el cuidado ofertado. Descriptores: Enfermería; Comunicación; Registros de enfermería; Seguridad del paciente; Investigación en Servicios de Salud. 


\section{INTRODUCTION}

The hospital environment is composed of a multiprofessional team with different educational levels and areas of activity. In this sense, inter-professional communication, whether verbal or nonverbal, must be evaluated for its clarity, objectivity and understanding, since this is a crucial factor for the continuity of quality care, with lower rates of adverse events and greater patient safety ${ }^{(1-2)}$.

Seeking to improve the care provided to patients, the medical record is one of the resources for achieving this proposal, since it is a form of continuous communication between professionals, and a legal document for the daily recording of information about the care provided by the health team ${ }^{(3)}$.

Authors $^{(4)}$ show that nursing accounts for half of the information about patient care, given that nursing professionals accompany patients for the 24 hours of the day ${ }^{(5)}$. Moreover, the nursing record is an ethical-legal duty to be performed by nurses and nursing technicians (NT) in all health settings ${ }^{(6-7)}$, standing out as an instrument that documents and qualifies the care provided. Although nursing records are essential and obligatory, their use is still incipient, something that reinforces the invisibility of the profession ${ }^{(8)}$.

Thus, by understanding the relevance of nursing notes, the Brazilian Federal Nursing Council (Cofen), via Resolution No. $0514 / 2016^{(9)}$, approved the publication of a guide on the main elements of patients' medical records for nursing professionals.

Therefore, nursing must compile the care provided to patients, their signs and symptoms, intercurrent events and responses to patients ${ }^{(10)}$. Furthermore, nursing records provide data that help in the establishment of nursing care plans and nursing evolution, acting as a subsidy for the Systematization of Nursing Care (Sistematização da Assistência de Enfermagem - SAE) and/or Systematization of Perioperative Nursing Care (Sistematização da Assistência de Enfermagem Perioperatória - SAEP) ${ }^{(11)}$.

Moreover, the analysis of these records can subsidize better care practices since it allows the development of strategies and actions aimed at improvements in care, and acts as legal support to the professional. This study is thus justified by the understanding that the lack or incompleteness of nursing notes interferes with the communication and continuity of care, which negatively affects the quality and safety of the care provided.

Given this discussion, the following guiding question is used: how do the nursing professionals of a public hospital in the Northeast region of Brazil in the city of Natal perform their records?

\section{OBJECTIVES}

To analyze the main non-conformities of the nursing records of a public hospital in the Northeast region of Brazil in the city of Natal.

\section{METHODS}

\section{Ethical aspects}

All ethical precepts involving research on human beings were followed in accordance with Resolution No. 466 of December 12, 2012. Data collection occurred after approval of the project by the Research Ethics Committee of Universidade Federal do Rio
Grande do Norte, no. 1,662,417, CAAE: 57947716.5.0000.5537, of August 4, 2016.

\section{Study design, location and period}

This is a descriptive, cross-sectional study with a quantitative approach. The study was conducted in a public hospital in the Northeast region of Brazil from October to December 2016. The nursing records of the first 10 days of hospitalization in 120 selected medical records from clinical and surgical wards. This period allowed the analysis of nursing professionals' communication, both at the time of patient admission and on subsequent days ${ }^{(12)}$.

\section{Population or sample: inclusion and exclusion criteria}

Sampling was conducted by convenience in both inpatient units evaluated. Records included for analysis were those of patients hospitalized for 10 days or more in the investigated area, in addition, the medical records of patients who consented to the study were included. Records excluded were those of patients whom were transferred to another unit or who refused to sign the informed consent form for the study.

\section{Study protocol}

A previously validated data extraction instrument was used during the data collection phase ${ }^{(13)}$. From this, the nursing records were investigated for the presence of date and time, use of acronyms and standardized abbreviations, legible handwriting, erasures and the identification of the professional. Aspects regarding the contents of the record were also observed. As common components in the records made by NT and nurses at the time of admission, adequacy was assessed for the presence of information about the patient's origin, identification of the companion, arrival conditions, concomitant diseases, life habits, presence of allergies and medication use (type, dosage and frequency) ${ }^{(9-10)}$.

Furthermore, both at admission and daily, the records were examined for the presence of information about the general conditions of the patient (level of consciousness, mood, personal hygiene, attitude, skin coloration, nutritional state, locomotion, description of excretions considering the type, consistency, odor and coloration), presence of devices, patient complaints, orientations given to the patient/ companion, care and procedures performed, and intercurrences ${ }^{(14)}$.

It must be stressed that at admission and in the following daily notes, the nurse is responsible for recording items about physical examination (evaluation of the neurological, respiratory, digestive, cardiovascular, nutritional, locomotor and genitourinary systems), which were also analyzed ${ }^{(14)}$.

\section{Analysis of results and statistics}

Data were tabulated, grouped and analyzed by simple descriptive statistics, using absolute and relative frequency in the 2013 Microsoft Excel software.

The Pareto Diagram was used to evaluate the main nonconformities found in the records made by nurses and NT, a standard quality management instrument to identify failures and their respective causes. 
From the Pareto principle, it is assumed that a small number of causes, around $20 \%$, is responsible for about $80 \%$ of the effects. Thus, the priority points for interventions on the root causes of essential problems are listed ${ }^{(13)}$.

\section{RESULTS}

Of the 120 records analyzed, only in 39 (32.5\%) it was possible to differentiate the records made by NT and the nurses, since there were some without the identification of the person in charge. It should be noted that the number of annotations verified in these 10 days varied, for 345 records in total made by NT and 56 by nurses.

Among the common variables of these records, the absence of time in the records by NT $(264 ; 76.6 \%)$ and nurses $(31 ; 55.4 \%)$ is evident. Moreover, erasures were found in the NT records (87; 25.7\%), as shown in Table 1.

Table 1 - Common elements of nursing team records, Natal, Rio Grande do Norte, Brazil, $2018(\mathrm{~N}=401)$

\begin{tabular}{|c|c|c|c|c|c|}
\hline \multirow[t]{2}{*}{ Variable } & & \multicolumn{2}{|c|}{$\begin{array}{l}\text { Nursing } \\
\text { technician } \\
(n=345)\end{array}$} & \multicolumn{2}{|c|}{$\begin{array}{l}\text { Nurse } \\
(n=56)\end{array}$} \\
\hline & & $\mathbf{n}$ & $\%$ & $\mathbf{n}$ & $\%$ \\
\hline Presence of date & $\begin{array}{l}\text { Yes } \\
\text { No }\end{array}$ & $\begin{array}{c}331 \\
14\end{array}$ & $\begin{array}{c}95.9 \\
4.1\end{array}$ & $\begin{array}{l}52 \\
04\end{array}$ & $\begin{array}{c}92.8 \\
7.2\end{array}$ \\
\hline Presence of time & $\begin{array}{l}\text { Yes } \\
\text { No }\end{array}$ & $\begin{array}{c}81 \\
264\end{array}$ & $\begin{array}{l}23.4 \\
76.6\end{array}$ & $\begin{array}{l}25 \\
31\end{array}$ & $\begin{array}{l}44.6 \\
55.4\end{array}$ \\
\hline Use of legible handwriting & $\begin{array}{l}\text { Yes } \\
\text { No }\end{array}$ & $\begin{array}{l}186 \\
159\end{array}$ & $\begin{array}{l}53.7 \\
45.3\end{array}$ & $\begin{array}{l}46 \\
10\end{array}$ & $\begin{array}{l}82.1 \\
17.9\end{array}$ \\
\hline Registration without any erasure & $\begin{array}{l}\text { Yes } \\
\text { No }\end{array}$ & $\begin{array}{c}264 \\
87\end{array}$ & $\begin{array}{l}76.3 \\
25.7\end{array}$ & $\begin{array}{l}55 \\
01\end{array}$ & $\begin{array}{c}98.2 \\
1.8\end{array}$ \\
\hline $\begin{array}{l}\text { Use of abbreviations and } \\
\text { standardized acronyms }\end{array}$ & $\begin{array}{l}\text { Yes } \\
\text { No }\end{array}$ & $\begin{array}{l}290 \\
55\end{array}$ & $\begin{array}{l}83.8 \\
15.2\end{array}$ & $\begin{array}{l}51 \\
05\end{array}$ & $\begin{array}{c}89.1 \\
8.9\end{array}$ \\
\hline
\end{tabular}

Regarding patient admission, Table 2 shows the inadequacy of the records in relation to data on the patient's origin, identification of the companion, information on arrival conditions, presence of concomitant diseases, life habits, presence of allergies and medication use - type, dosage and frequency -, both by NT and by nurses.

Regarding the identification by professionals, the absence of the professional's name $(223,58.9 \%)$, professional category designation $(303,87.9 \%)$ and identification of the nursing council number $(272,78.8 \%)$ by NT, as shown in Table 3.

In the analysis of non-conformities via the Pareto Diagram, the absence of the professional category and the nursing council number of the responsible were the essential problems identified, accounting for $41.8 \%$ of the non-conformities in NT records. Regarding nurses, the absence of time and illegible handwriting can be highlighted in $61.2 \%$ of the records (Figure 1).

Regarding the content of these documents, nurses have fewer records about the level of consciousness $(17 ; 30.4 \%)$ and the presence of devices $(25 ; 44.7 \%)$. In the nursing technician's records, the patient's attitude $(280 ; 81.2 \%)$, form of locomotion $(286 ; 82.9 \%)$ and care procedures conducted $(92 ; 26.7 \%)$ present few data. Moreover, the records of both present deficits regarding the registry of the patient's mood and personal hygiene data, as shown in Table 4.

Furthermore, regarding the physical examination performed by the nurse, a greater deficit is identified in the evaluation records of the genitourinary and locomotor systems, followed by the neurological, respiratory, digestive, cardiovascular and nutritional systems.

Table 2 - Admission records made by the nursing team, Natal, Rio Grande do Norte, Brazil, $2018(\mathrm{~N}=43)$

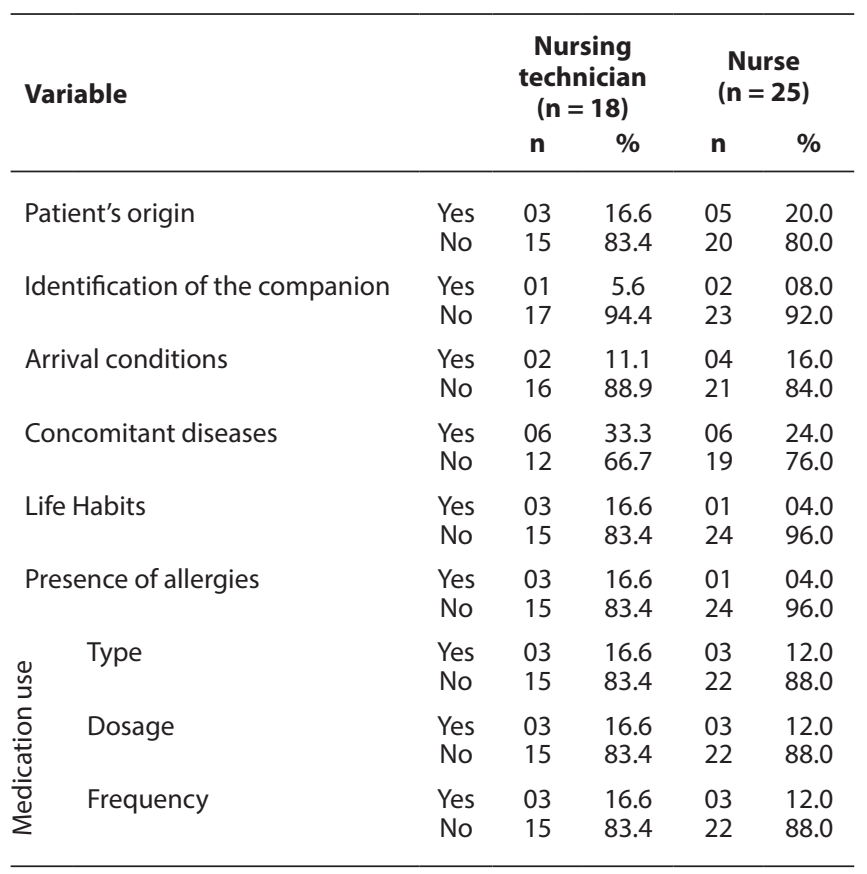

Table 3 - Identification of the professional responsible for the nursing record, Natal, Rio Grande do Norte, Brazil, 2018 ( $N=401)$

\begin{tabular}{lcccccc}
\hline Variable & \multicolumn{3}{c}{$\begin{array}{c}\text { Nursing } \\
\text { technician } \\
\text { (n= 345) }\end{array}$} & \multicolumn{2}{c}{$\begin{array}{c}\text { Nurse } \\
(\mathbf{n}=\mathbf{5 6})\end{array}$} \\
& & \multicolumn{2}{c}{$\mathbf{n}$} & $\%$ & $\mathbf{n}$ & $\%$ \\
\hline \multirow{2}{*}{ Name } & Yes & 142 & 41.1 & 49 & 87.5 \\
& No & 223 & 58.9 & 07 & 12.5 \\
Professional category & Yes & 42 & 12.1 & 53 & 94.6 \\
& No & 303 & 87.9 & 03 & 05.4 \\
COREN Number & Yes & 73 & 21.2 & 50 & 89.2 \\
& No & 272 & 78.8 & 06 & 10.8 \\
\hline
\end{tabular}

Table 4 - Daily records of the nursing team, Natal, Rio Grande do Norte, Brazil, $2018(\mathrm{~N}=401)$

\begin{tabular}{|c|c|c|c|c|c|}
\hline \multirow[t]{2}{*}{ Variable } & & \multicolumn{2}{|c|}{$\begin{array}{l}\text { Nursing } \\
\text { technician } \\
(n=345)\end{array}$} & \multicolumn{2}{|c|}{$\begin{array}{l}\text { Nurse } \\
(n=56)\end{array}$} \\
\hline & & $\mathbf{n}$ & $\%$ & $\mathbf{n}$ & $\%$ \\
\hline Level of consciousness & $\begin{array}{l}\text { Yes } \\
\text { No }\end{array}$ & $\begin{array}{c}312 \\
33\end{array}$ & $\begin{array}{l}90.4 \\
09.6\end{array}$ & $\begin{array}{l}39 \\
17\end{array}$ & $\begin{array}{l}69.6 \\
30.4\end{array}$ \\
\hline Mood & $\begin{array}{l}\text { Yes } \\
\text { No }\end{array}$ & $\begin{array}{c}79 \\
266\end{array}$ & $\begin{array}{l}22.8 \\
77.2\end{array}$ & $\begin{array}{l}20 \\
36\end{array}$ & $\begin{array}{l}35.7 \\
64.3\end{array}$ \\
\hline Personal hygiene & $\begin{array}{l}\text { Yes } \\
\text { No }\end{array}$ & $\begin{array}{l}139 \\
206\end{array}$ & $\begin{array}{l}40.2 \\
59.8\end{array}$ & $\begin{array}{l}17 \\
39\end{array}$ & $\begin{array}{l}30.3 \\
69.7\end{array}$ \\
\hline Attitude & $\begin{array}{l}\text { Yes } \\
\text { No }\end{array}$ & $\begin{array}{c}65 \\
280\end{array}$ & $\begin{array}{l}18.8 \\
81.2\end{array}$ & $\begin{array}{l}17 \\
39\end{array}$ & $\begin{array}{l}30.3 \\
69.7\end{array}$ \\
\hline Skin coloration & $\begin{array}{l}\text { Yes } \\
\text { No }\end{array}$ & $\begin{array}{c}71 \\
274\end{array}$ & $\begin{array}{l}20.5 \\
79.5\end{array}$ & $\begin{array}{l}07 \\
49\end{array}$ & $\begin{array}{l}12.5 \\
87.5\end{array}$ \\
\hline Nutritional status & $\begin{array}{l}\text { Yes } \\
\text { No }\end{array}$ & $\begin{array}{l}113 \\
232\end{array}$ & $\begin{array}{l}32.7 \\
67.3\end{array}$ & $\begin{array}{l}22 \\
34\end{array}$ & $\begin{array}{l}39.2 \\
60.8\end{array}$ \\
\hline
\end{tabular}


Table 4 (concluded)

\begin{tabular}{|c|c|c|c|c|c|}
\hline \multirow[t]{2}{*}{ Variable } & & \multicolumn{2}{|c|}{$\begin{array}{l}\text { Nursing } \\
\text { technician } \\
(n=345)\end{array}$} & \multicolumn{2}{|c|}{$\begin{array}{c}\text { Nurse } \\
(n=56)\end{array}$} \\
\hline & & $\mathbf{n}$ & $\%$ & $\mathbf{n}$ & $\%$ \\
\hline Locomotion & $\begin{array}{l}\text { Yes } \\
\text { No }\end{array}$ & $\begin{array}{c}59 \\
286\end{array}$ & $\begin{array}{l}17.1 \\
82.9\end{array}$ & $\begin{array}{l}12 \\
26\end{array}$ & $\begin{array}{l}31.5 \\
68.5\end{array}$ \\
\hline Type of excretions & $\begin{array}{l}\text { Yes } \\
\text { No }\end{array}$ & $\begin{array}{l}170 \\
175\end{array}$ & $\begin{array}{l}49.2 \\
50.8\end{array}$ & $\begin{array}{l}21 \\
35\end{array}$ & $\begin{array}{l}37.5 \\
62.5\end{array}$ \\
\hline Consistency of excretions & $\begin{array}{l}\text { Yes } \\
\text { No }\end{array}$ & $\begin{array}{c}39 \\
306\end{array}$ & $\begin{array}{l}11.3 \\
88.7\end{array}$ & $\begin{array}{l}10 \\
46\end{array}$ & $\begin{array}{l}17.8 \\
82.2\end{array}$ \\
\hline Odor of excretions & $\begin{array}{l}\text { Yes } \\
\text { No }\end{array}$ & $\begin{array}{c}58 \\
287\end{array}$ & $\begin{array}{l}16.8 \\
83.2\end{array}$ & $\begin{array}{l}09 \\
47\end{array}$ & $\begin{array}{l}16.0 \\
84.0\end{array}$ \\
\hline Coloring of excretions & $\begin{array}{l}\text { Yes } \\
\text { No }\end{array}$ & $\begin{array}{c}47 \\
298\end{array}$ & $\begin{array}{l}13.6 \\
86.4\end{array}$ & $\begin{array}{l}10 \\
46\end{array}$ & $\begin{array}{l}17.8 \\
82.2\end{array}$ \\
\hline Device usage & $\begin{array}{l}\text { Yes } \\
\text { No }\end{array}$ & $\begin{array}{c}278 \\
67\end{array}$ & $\begin{array}{l}80.5 \\
19.5\end{array}$ & $\begin{array}{l}31 \\
25\end{array}$ & $\begin{array}{l}55.3 \\
44.7\end{array}$ \\
\hline Patient complaints & Yes & 137 & 39.7 & 22 & 39.2 \\
\hline Instructions for the patient/companion & $\begin{array}{l}\text { Yes } \\
\text { No }\end{array}$ & $\begin{array}{c}38 \\
307\end{array}$ & $\begin{array}{l}11.0 \\
89.0\end{array}$ & $\begin{array}{l}09 \\
47\end{array}$ & $\begin{array}{l}16.0 \\
84.0\end{array}$ \\
\hline Care and procedures performed & $\begin{array}{l}\text { Yes } \\
\text { No }\end{array}$ & $\begin{array}{c}253 \\
92\end{array}$ & $\begin{array}{l}73.3 \\
26.7\end{array}$ & $\begin{array}{l}40 \\
16\end{array}$ & $\begin{array}{l}71.4 \\
28.6\end{array}$ \\
\hline Procedures and intercurrent event & $\begin{array}{l}\text { Yes } \\
\text { No }\end{array}$ & $\begin{array}{l}163 \\
157\end{array}$ & $\begin{array}{l}50.9 \\
49.1\end{array}$ & $\begin{array}{l}31 \\
25\end{array}$ & $\begin{array}{l}55.3 \\
44.7\end{array}$ \\
\hline
\end{tabular}

\section{DISCUSSION}

The results presented reveal the incompleteness and/or lack of records during the analyzed days, a fact that differs from what is established by the code of ethics of the profession ${ }^{(6)}$ when affirming that it is the right, duty and responsibility of the nursing team to record information related to their care in medical records and other documents proper to nursing.

Despite the ethical responsibility, legal support, increased visibility of the profession and safety in the care that the records can provide, studies ${ }^{(15-16)}$ point out flaws in nursing documents, since their creation and quality can be influenced by factos like the high demand for services, work overload, insufficient number of professionals, permanent education deficits, lack of motivation related to poor working conditions, low pay, language complexity and ineffective team communication ${ }^{(17)}$.

Thus, among the analyzed records, in addition to the lack of notes on some days, the lack of time recording, and the identification of the responsible professional, as well as the presence of erasures and incomplete notes in the daily nursing records can also be highlighted as non-conformities.

Regarding the absence of time in the records, once the chronological order of the care provided is not informed, authors ${ }^{(15)}$ mention that it is impossible to know the exact time when a given care procedure was conducted. The changes that the patient presented during hospitalization were also analyzed ${ }^{(18)}$.

Erasures were also observed in the NT records, which is in agreement with the guide provided by Cofen ${ }^{(9)}$. We must emphasize that erasures in these documents, from a legal point of view, can have lead to legal complications since these documents serve as a defense for the professional; thus, they must be clear, objective, precise, legible and have no erasures ${ }^{(7)}$.

Regarding the lack of identification of the professionals in the records, it is exposed that the practice also contradicts its legal aspect ${ }^{(7)}$, as stressed by a study ${ }^{(19)}$ that showed the lack of identification and stamp of the professional who performed the task.

Considering the analysis of the Pareto Diagram, we can highlight the effective intervention in permanent education actions as a priority, developing actions on the importance of documenting the identification of the professional, the time when the care procedure was conducted, and the use of legible handwriting since complete records facilitate the communication between the team, enable continuity of care, and result in quality of care ${ }^{(20)}$. Thus, the idea that these records are merely another bureaucratic obligation must be overcome ${ }^{(21)}$.

Moreover, gaps in the knowledge of nursing professionals about what, how
Figure 1 - Pareto diagram of non-conformities in the records of nursing technicians $(A)$ and nurses (B). Natal, Rio Grande do Norte, Brazil, 2018 
and when to register lead to the lack of crucial information in patients' records such as the consciousness level, device use and physical examination. A study ${ }^{(22)}$ states that the incompleteness of nursing records is also influenced by the shortage of nurses and NT in relation to the number of patients and, consequently, increase in the work overload.

In this sense, although some notes are exclusive to the nurse (such as the physical examination), the entire nursing team must collaborate for the provision of a safe and quality care, both in its evaluation and execution, since the lack of records is an obstacle to SAE and patient safety. Therefore, continuous training actions conducted by the institution for the entire health team can enable the understanding of the importance of complete records; thus, collaborating to its effective execution ${ }^{(23)}$.

\section{Study limitations}

We can highlight the analysis of a single reality as a limitation of this study, given that it may represent approximations or disparities from others already studied, making it necessary to investigate the situation of other services. Moreover, we must emphasize that this is a cross-sectional study, i.e., it pictures the situation at the investigated institution with temporal limitation, and may not represent the continuous care service of such institution.

\section{Contributions to the field of nursing}

This study can be used to support better care practices, since its evaluation enables the development of strategies and actions aimed at improvements in care and that would also function as legal support to nursing professionals. Moreover, we must highlight the possible strategies to be taken by the analyzed institution or in other similar realities, such as the training and continuous training of health professionals, as well as educational activities.

\section{CONCLUSIONS}

This study showed that the nursing professionals of the studied hospital perform their records in an incomplete manner and that they often do not document the care provided.

The main non-conformities of the nursing records were the absence of the professional category and the nursing council number of nursing technicians. For nurses, the non-conformities were the absence of time, use of illegible handwriting, and lack of information on the evaluation of the locomotor and genitourinary systems. We must emphasize that both nurses and NT presented non-conformities regarding the recording of patient admission.

The incompleteness and scarcity of records in the period evaluated thus reflects a common reality in the various nursing care sectors. Therefore, the act of recording the care provided constitutes a challenge in the routine of the nursing team.

We also emphasize that nursing records cannot be seen as mere bureaucratic obligations, nursing professionals must comprehend their importance and the implications arising from the incompleteness of this document.

Therefore, the technical-scientific competence of the nursing team is indispensable for complete records. Thus, we reflect on the need of institutions and councils related to nursing to emphasize and promote measures that help in the training of professionals so no impairments in the quality of the care provided and in patient safety occur.

\section{REFERENCES}

1. Blair W, Smith B. Nursing documentation: frameworks and barriers. Contemp Nurse. 2012;41(2):160-8. doi: 10.5172/conu.2012.41.2.160

2. Broca PV, Ferreira MA. Communication process in the nursing teama based on the dialogue between Berlo and King. Esc Anna Nery Rev Enferm. 2015;19(3):467-74. doi: 10.5935/1414-8145.20150062

3. Carneiro SM, Dutra HS, Costa FM, Mendes SE, Arreguy-Sena C. Uso de abreviaturas nos registros de enfermagem em um hospital de ensino. Rev Rene. 2016;17(2):208-16. doi: 10.15253/2175-6783.2016000200008

4. Barral LNM, Ramos LH, Vieira MA, Dias OV, Souza LPS. Análise dos registros de enfermagem em prontuários de pacientes em um hospital de ensino. REME - Rev Min Enferm [Internet]. 2012 [cited 2017 Jun 07];16(2):188-93. Available from: http://www.reme.org.br/content/ imagebank/pdf/v16n2a06.pdf

5. França FM, Ferrari R. Estresse ocupacional e crônico e o setor de atuação dos profissionais de enfermagem da rede hospitalar. Rev Eletr Gest Saúde [Internet]. 2012 [cited 2017 Jun 07];3(1):318-32. Available from: https://dialnet.unirioja.es/descarga/articulo/5555760.pdf

6. Conselho Federal de Enfermagem (Cofen). Resolução Cofen $n^{\circ} 311 / 2007$. Aprova a reformulação do código de ética dos profissionais de enfermagem [Internet]. Rio de Janeiro: Cofen; 2007 [cited 2017 Jun 08]. Available from: http://www.cofen.gov.br/resoluocofen-3112007_4345.html

7. Conselho Federal de Enfermagem (Cofen). Resolução Cofen n 545/2017. Revogou a Resolução Cofen no 191/1996. Dispõe sobre a anotação de enfermagem e mudança nas siglas das categorias profissionais [Internet]. Brasília: Cofen; 2017 [cited 2017 Jun 08]. Available from: http:// www.cofen.gov.br/resolucao-cofen-no-05452017_52030.html

8. Maziero VG, Vannuchi MTO, Haddad MCL, Vituri DW, Tada CN. Quality control of patients' monitoring records in a university hospital. REME Rev Min Enferm. 2013;17(1):165-70. doi: 10.5935/1415-2762.20130014

9. Conselho Federal de Enfermagem (Cofen). Resolução Cofen no 514/2016. Aprova o Guia de recomendações para registro de enfermagem no prontuário do paciente e outros documentos de enfermagem [Internet]. Brasília: Cofen; 2016 [cited 2017 Jun 10]. Available from: http:// www.cofen.gov.br/resolucao-cofen-no-05142016_41295.html 
10. Conselho Federal de Enfermagem (Cofen). Guia de recomendações para registro de enfermagem no prontuário do paciente e outros documentos de enfermagem - versão web [Internet]. Brasília: Cofen; 2016 [cited 2017 Jun 10]. Available from: http://www.cofen.gov.br/ wp-content/uploads/2016/08/Guia-de-Recomenda\%C3\%A7\%C3\%B5es-CTLN-Vers\%C3\%A3o-Web.pdf

11. Silva TG, Santos RM, Crispim LMC, Almeida LMWS. Conteúdo dos registros de enfermagem em hospitais: contribuições para o desenvolvimento do processo de enfermagem. Enferm Foco. 2016;7(1):24-7. doi: 10.21675/2357-707X.2016.v7.n1

12. Chazan ACS, Silveira LMC, Favoreto CAO. Revisão de prontuário como estratégia de ensino-aprendizagem da medicina centrada na pessoa em um ambulatório universitário no município do Rio de Janeiro. Rev Bras Med Fam Comunidade. 2014;9(30):96-103. doi: 10.5712/ $\operatorname{rbmfc9}(30) 700$

13. Alves KYA. Comunicação escrita dos profissionais de saúde em hospitais públicos do Rio Grande do Norte [dissertação] [Internet]. Natal: Universidade Federal do Rio Grande do Norte; 2017 [cited 2018 Aug 10]. Available from: https://repositorio.ufrn.br/jspui/ handle/123456789/24515

14. Barros ALBL. Anamnese e exame físico. $3^{\text {a }}$ ed. Porto Alegre: Artmed; 2016.

15. Costa FM, Rodrigues AO. Auditoria operacional: não conformidades em registros de enfermagem. Rev Bras Pesq Ciênc Saúde [Internet]. 2014 [cited 2017 Jun 17];1(1):25-8. Available from: http://revistas.icesp.br/index.php/RBPeCS/article/view/8/2

16. Morais CGX, Batista EMS, Castro JFL, Assunção SS, Castro GMO. Registros de enfermagem em prontuário e suas implicações na qualidade assistencial segundo os padrões de acreditação hospitalar: um novo olhar da auditoria. Revista ACRED [Internet]. 2015 [cited 17 Jun 2017];5(9):64-84. Available from: https://dialnet.unirioja.es/servlet/articulo?codigo=5626617

17. Magalhães AM, Dall'Agnol CM, Marck PB. Nursing workload and patient safety - a mixed method study with an ecological restorative approach. Rev Latino-Am Enfermagem. 2013;21(spec):146-54. doi: 10.1590/S0104-11692013000700019

18. Silva JA, Grossi ACM, Haddad MCL, Marcon SS. Avaliação da qualidade das anotações de enfermagem em unidade semi-intensiva. Esc Anna Nery Rev Enferm. 2012;16(3):576-82. doi: 10.1590/S1414-81452012000300021

19. Franco MTG, Akemi EN, D'Inocento M. Evaluation of the nursing records in the medical records of patients hospitalized in an internal medicine unit. Acta Paul Enferm. 2012;25(2):163-70. doi: 10.1590/S0103-21002012000200002

20. Lucena AF. Processo de enfermagem: interfaces com o processo de acreditação hospitalar. Rev Gaúcha Enferm [Internet]. 2013 [cited 2017 Jul 03];34(4):12-3. Available from: http://seer.ufrgs.br/index.php/RevistaGauchadeEnfermagem/article/view/45306

21. Gomes DC, Cubas MR, Pleis LE, Shmeil MAH, Peluci APVD. Terms used by nurses in the documentation of patient progress. Rev Gaúcha Enferm. 2016;37(1):e53927. doi: 10.1590/1983-1447.2016.01.53927

22. Silveira LL, Almeida MA, Silva MB, Nomura ATG. Nursing registries of educational actions for patients submitted to hip arthroplasty. Rev Eletr Enf. 2015;17(4):1-8. doi: 10.5216/ree.v17i4.31636

23. Conselho Federal de Enfermagem (Cofen). Resolução n 272, de 27 de agosto de 2002. Dispõe sobre a Sistematização da Assistência de Enfermagem (SAE) nas instituições de saúde brasileiras [Internet]. Brasília: Cofen; 2002 [cited 2017 Jul 03]. Available from: http://www.cofen. gov.br/resoluo-cofen-2722002-revogada-pela-resoluao-cofen-n-3582009_4309.html 